\title{
Meteorological Rocket Data, McMurdo Station, Antarctica, 1962-1963
}

\author{
RAYMOND S. BRIGGS \\ Schellenger Research Laboralories, Texas Western College, El Paso
}

(Manuscript received 10 August 1964)

\begin{abstract}
ABSTRAC $\Gamma$
Wind and temperature measurements using meteorological sounding rockets were made in the upper atmosphere at McMurdo Station, Antarctica, between June 1962 and October 1963. These rocket soundings were the first to be made above normal radiosonde levels in the Southern Hemisphere. The most active and interesting period was the September-October early spring period; this period was marked by the reversal of wind direction and "explosive" warming. Strong zonal winds appeared near $35 \mathrm{~km}$ during late September. This "jet" completely disappeared over McMurdo Station by the end of October and was replaced by light easterly winds and warmer temperatures. The "explosive" warming occurred during the decline of this strong wind system.
\end{abstract}

\section{Introduction}

The development and expansion of the Meteorological Rocket Network (MRN) during the past five years have been primarily accomplished in the Northern Hemisphere. The northernmost stations are Ft. Greely, Alaska, at $64^{\circ} 00^{\prime} \mathrm{N}$ and Ft. Churchill, Canada, at $58^{\circ} 44^{\prime} \mathrm{N}$. The network has stabilized with six active stations making coordinated and simultaneous rocket firings. McMurdo Station in Antarctica was the only station making high altitude soundings in the Southern Hemisphere, and at $77^{\circ} 53^{\prime} \mathrm{S}$ had no counterpart in the Northern Hemisphere.

The meteorological rocket program at McMurdo Station was supported under a research grant to Schellenger Research Laboratories of Texas Western College by the National Science Foundation. Rocket firings were conducted during an 18-month period, from June of 1962 through October of 1963. This 18-month period covered two Antarctic winter seasons and one summer season. Twenty-eight successful soundings were made using the ARCAS sounding rocket; 22 of these yielded usable temperature data. For the purposes of analyzing the rocket data from McMurdo Station, all available radiosonde data were obtained. However, the altitudes attained by the radiosondes during the winter season rarely exceeded $15 \mathrm{~km}$, well below altitudes where significant changes in circulation were detected.

McMurdo Station is located at $785,168 \mathrm{E}$, approximately 800 miles from the south geographic pole and 2400 miles south of New Zealand. The extreme surface weather conditions were generally less favorable to the operation of rocket launching and instrumentation tracking facilities than at other MRN stations. Observations were limited by the small number of available rockets during the 18-month period. In spite of the relatively low number of soundings (28), the time- height cross sections of temperature and winds are sufficiently detailed to yield some interesting conclusions.

One of the most interesting questions which arises in analyzing the data concerns the correlation of Antarctic and Arctic data: Is there any similarity between Arctic and Antarctic circulation patterns; and if so, to what extent?

Since the Arctic stratosphere has been under intense observation for a number of years, certain features of the circulation and temperature profiles have been repeatedly observed. The formation of the polar night jet stream has been speculated upon for a considerable period and has been observed regularly over the last five years in rocketsonde observations at Ft. Greely and Ft. Churchill.

The seasonal conditions of the Arctic stratosphere, the predominantly westerly winds in winter above 20 $\mathrm{km}$, the observed times of summer-winter reversals, and the disturbed conditions which exist during these reversals are well documented (Kellogg and Schilling, 1950; Murgatroyd, 1957; Teweles and Finger, 1958; Palmer, 1959). Unfortunately such is not the case for the Antarctic stratosphere. During the IGY, 1957-1958, the first Antarctic meteorological data were recorded on a synoptic basis, when a coordinated program was initially undertaken. However, the sparseness of observations, particularly in the southern oceans, rendered analysis difficult.

As data from the Antarctic became available, meteorologists recognized that certain similarities existed between the two hemispheres (Palmer, 1959; Wexler, 1961). A symposium in Melbourne, Australia, in February of 1959, was the first to be held concerning Antarctic IGY meteorological data. The proceedings of of the symposium were subsequently published (Dwyer, L. J., ed., 1960). 
The initial rocketsonde program at McMurdo Station was undertaken to shed some light on the following questions:

(1) Does the Southern Hemisphere exhibit the seasonal zonal wind structure that is present in the Arctic? If so, at what altitudes, with what magnitudes, and over what time intervals?

(2) Does a polar night jet stream exist in the Southern Hemisphere? When does it form and with what strength?

(3) When does the sudden warming period usually occur, and at what altitude does the disturbance originate?

(4) What temperature ranges exist in the upper levels of the stratosphere?

\section{Operational procedure}

All rocket firings at McMurdo Station were made with Arcas vehicles manufactured by Atlantic Research Corporation. The Arcas motor is a solid-fuel, endburning sounding rocket approximately $6 \mathrm{ft}$ long by $4 \frac{1}{2}$ inches in diameter, capable of carrying up to $15 \mathrm{lb}$ in 230 cubic inches to altitudes near $65 \mathrm{~km}$ (for sea-level launches). Burning time is approximately 30 seconds during which time the vehicle attains 16 $\mathrm{km}$ and a speed of 1100 meters per second. The vehicle coasts for an additional 100 seconds; near apogee, a pyrotechnic charge separates the payload from the expended motor.

The payload for this program was the Delta instrument package manufactured by the Lexington Army Depot in Lexington, Kentucky, and the $50 \%$ reflectivity parachute made by Atlantic Research Corporation. The instrument package was essentially an AN/AMT-4 transmitter, modified to use a VECO 10-mil bead thermistor as the temperature sensing element. The instrument frequently centered at $1680 \mathrm{mc}$ so that standard Ground Meteorological Detectors (AN/GMD-1A) could be used for tracking. The 15-ft metalized nylon parachute provided a passive wind sensing radar target.

Only one parameter, temperature, was obtained from the package as it descended on parachute. A fixed calibration frequency was transmitted from the instrument at intervals of approximately 5 minutes to allow in-flight calibration of the temperature trace.

During the initial nine months of the program, two Ground Meteorological Detectors were used to determine instrument position. Azimuth and elevation angles of the two machines, as well as the length of the baseline between them, were used for a triangulation of instrument altitude and horizontal position. All computations were performed on a Bendix G-15 digital computer. The temperature record was combined with altitude-time for temperature vs. altitude.
Wind data were obtained by the conversion of sensor displacement during a fixed time interval into average velocity components. No correction was made to these components for errors due to the fall rate of the parachute. The altitude fixed for each wind component was the average altitude of the parachute during the time interval. Accuracy of the wind measurement using this procedure is considered to be within $\pm 3 \mathrm{~m} \mathrm{sec}^{-1}$ for the 15-ft parachute (Miers, 1963). A detailed discussion of the entire procedure may be found in Rotolante (1963).

The last nine soundings were tracked with an AAM33C Fire Control System track radar which had been modified for use in tracking the Arcas parachute. Radar and Ground Meteorological Detector were slaved together for acquistion of the parachute. Data reduction techniques were similar for this tracking system with the exception that altitude and horizontal position data were obtained from radar plotting boards.

Reduction of the temperature trace was similar to the reduction of the radiosonde temperature trace. The major difference was that each rocketsonde thermistor was calibrated separately. Drift of the standard reference ordinate was applied proportionately to the temperature ordinate, and the corrected ordinate was correlated to temperature by the manufacturer's calibration. Temperature data are considered accurate to plus or minus 1. $0 \mathrm{C}$ at altitudes below $40 \mathrm{~km}$ and within plus or minus $5.0 \mathrm{C}$ between 40 and $50 \mathrm{~km}$ (Wagner, 1961). Above $50 \mathrm{~km}$, the corrections outlined by Wagner (1961) should be applied for more consistent results. A complete profile was obtained for each sounding as, for example, the 16 January 1963 sounding shown in Fig. 1. Radiosonde data were used to complete the profile since, for the most part, the parachute was out of tracking range below $15 \mathrm{~km}$. Wherever possible, radiosonde and rocketsonde data were compared over the range in altitude where the measurements overlap. In a few cases the rocketsonde temperature measurements were adjusted to conform more closely with radiosonde temperatures. This has been the accepted procedure for rocketsonde observations, and in each case the adjustment was no greater than $10 \mathrm{C}$. A complete summary of the successful rocket soundings is shown in Table 1.

\section{Seasonal wind structure}

Each of the individual soundings was used to obtain a time-height cross section of zonal winds as shown in Figs. 2 and 3. It appears from inspection that the Antarctic year could best be divided into three "seasons": summer, winter, and late winter or early spring. The characteristics of each "season" are different: Summer is characterized by light easterly winds, increasing in strength above $40 \mathrm{~km}$; winter exhibits westerly winds increasing in magnitude as the season progresses; late winter is the most turbulent, character- 


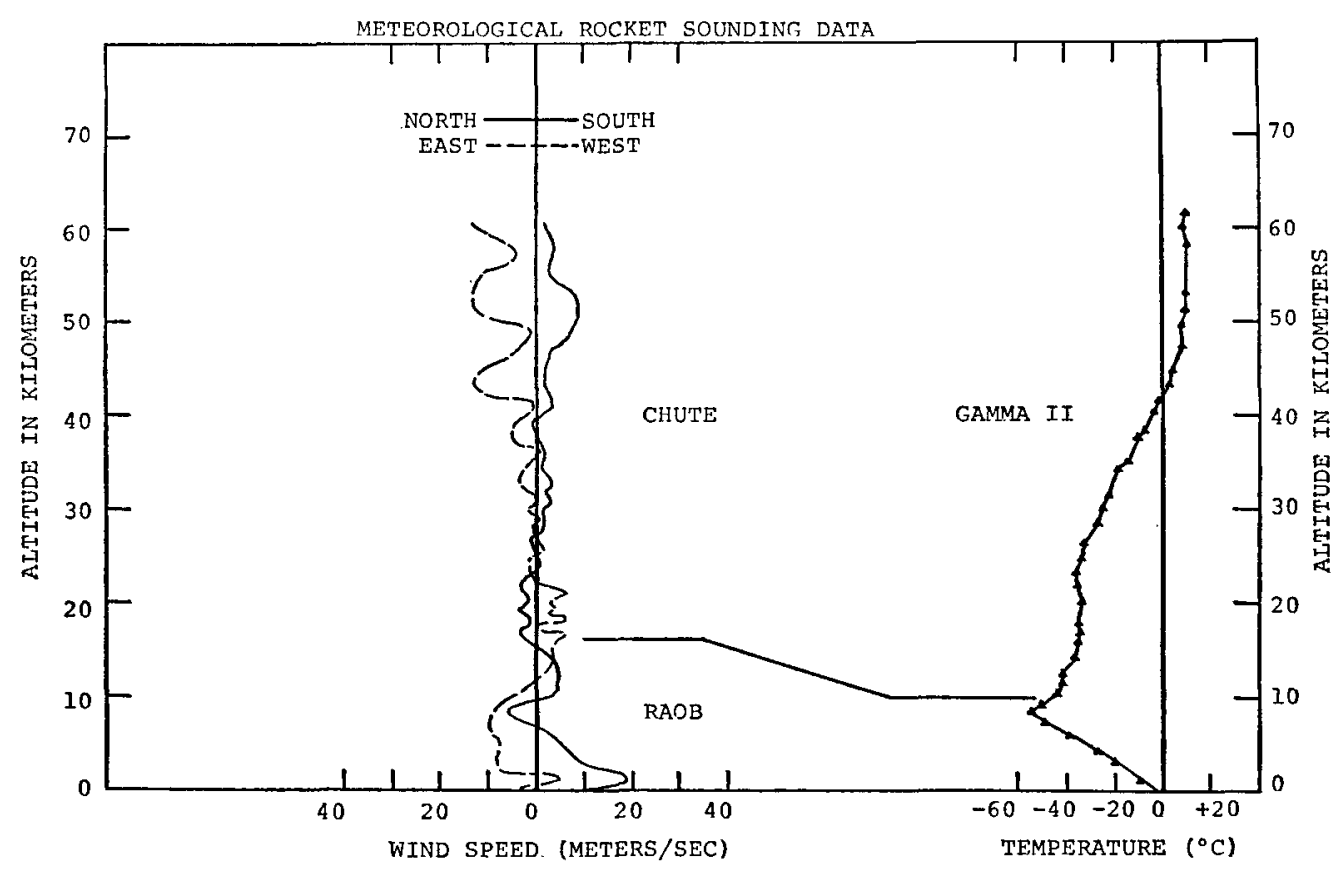

MCMURDO STATION-ANTARCTICA-16 JANUARY 1963-0445Z

FIG. 1. Meteorological rocket sounding profile, McMurdo Station, Antarctica, 16 January 1963.

Table 1. Summary of rocket firings, McMurdo Station, Antaractica.

\begin{tabular}{|c|c|c|c|c|c|c|}
\hline Date & $\begin{array}{l}\text { Time } \\
\text { (GMT) }\end{array}$ & $\begin{array}{l}\text { Type } \\
\text { rocket }\end{array}$ & $\begin{array}{l}\text { Wind } \\
\text { sensor }\end{array}$ & $\begin{array}{l}\text { Temp. } \\
\text { sensor }\end{array}$ & $\begin{array}{l}\text { Temp. track } \\
(\times 10 \text { meters })\end{array}$ & $\begin{array}{l}\text { Wind track } \\
\text { (X10 meters) }\end{array}$ \\
\hline 19 June 1962 & $1633 Z$ & Arcas & Chute & Gamma & $4400-2262$ & $3148-2222$ \\
\hline 21 July 1962 & $0551 Z$ & Arcas & Chute & Gamma & $5554-1956$ & $5114-2090$ \\
\hline 16 Aug 1962 & $1539 Z$ & Arcas & Chute & Gamma & 4136-2084 & $4114-2168$ \\
\hline 11 Sept 1962 & $1732 Z$ & Arcas & Chute & Gamma & $6242-2216$ & $6294-2228$ \\
\hline 21 Sept 1962 & $0314 Z$ & Arcas & Chute & \multicolumn{2}{|c|}{ Broken Thermistor } & $6060-3480$ \\
\hline 27 Sept 1962 & $0419 Z$ & Arcas & Chute & Gamma & $6666-1628$ & $6944-2152$ \\
\hline 03 Oct 1962 & $0334 Z$ & Arcas & Chute & Gamma & $6114-1978$ & $6612-2340$ \\
\hline 18 Oct 1962 & $1634 Z$ & Arcas & Chute & Gamma II & $5060-2256$ & $3140-2280$ \\
\hline 03 Nov 1962 & $0420 Z$ & Arcas & Chute & \multicolumn{2}{|c|}{ Broken Thermistor } & $2816-1590$ \\
\hline 07 Nov 1962 & $1635 Z$ & Arcas & Chute & Gamma II & $5456-2338$ & $5460-2038$ \\
\hline 15 Nov 1962 & $0547 Z$ & Arcas & Chute & \multicolumn{2}{|c|}{ Broken Thermistor } & $6514-1844$ \\
\hline 28 Nov 1962 & $0314 Z$ & Arcas & Chute & Gamma II & $4892-1290$ & $2864-1254$ \\
\hline 05 Dec 1962 & $0530 Z$ & Arcas & Chute & Gamma II & $4423-1969$ & $4396-1568$ \\
\hline 12 Dec 1962 & $0417 \mathrm{Z}$ & Arcas & Chute & Gamma II & $4640-1456$ & $4620-1394$ \\
\hline $21 \mathrm{Dec} 1962$ & $0349 Z$ & Arcas & Chute & Delta & $6522-1006$ & 63562028 \\
\hline $09 \mathrm{Jan} 1963$ & $0320 Z$ & Arcas & Chute & Delta & $6110-1530$ & $6318-2466$ \\
\hline 16 Jan 1963 & $0445 \mathrm{Z}$ & Arcas & Chute & Delta & $6166-1080$ & $6044-1626$ \\
\hline $06 \mathrm{Feb} 1963$ & $0535 Z$ & Arcas & Chute & Delta & $5890-0010$ & $5232-0934$ \\
\hline 27 Feb 1963 & $0430 Z$ & Arcas & Chute & \multicolumn{2}{|c|}{$\begin{array}{l}\text { Broken Thermistor } \\
\text { Broken Thermistor }\end{array}$} & $6208-1038$ \\
\hline 24 Apr 1963 & $0100 Z$ & Arcas & Chute & \multicolumn{2}{|c|}{ Broken Thermistor } & $4148-1856$ \\
\hline 16 May 1963 & $0340 Z$ & Arcas & Chute & Delta & $3780-1926$ & $3426-1904$ \\
\hline 29 July 1963 & $0348 Z$ & Arcas & Chute & Delta & $4510-1230$ & $4070-1002$ \\
\hline 14 Aug 1963 & $0230 Z$ & Arcas & Chute & \multicolumn{2}{|c|}{ Broken Thermistor } & $3684-1060$ \\
\hline 23 Aug 1963 & $0303 Z$ & Arcas & Chute & Delta & $3598-1358$ & $3340-1150$ \\
\hline 17 Sept 1963 & $0330 Z$ & Arcas & Chute & Delta & $4386-2106$ & $5480-2412$ \\
\hline 18 Sept 1963 & $0230 \mathrm{Z}$ & Arcas & Chute & Delta & $5046-1670$ & $4682-2334$ \\
\hline 27 Sept 1963 & $0300 Z$ & Arcas & Chute & Delta & $4010-1610$ & $4810-1694$ \\
\hline 03 Oct 1963 & $0330 \mathrm{Z}$ & Arcas & Chute & Delta & $2478-1456$ & $2336-1048$ \\
\hline
\end{tabular}




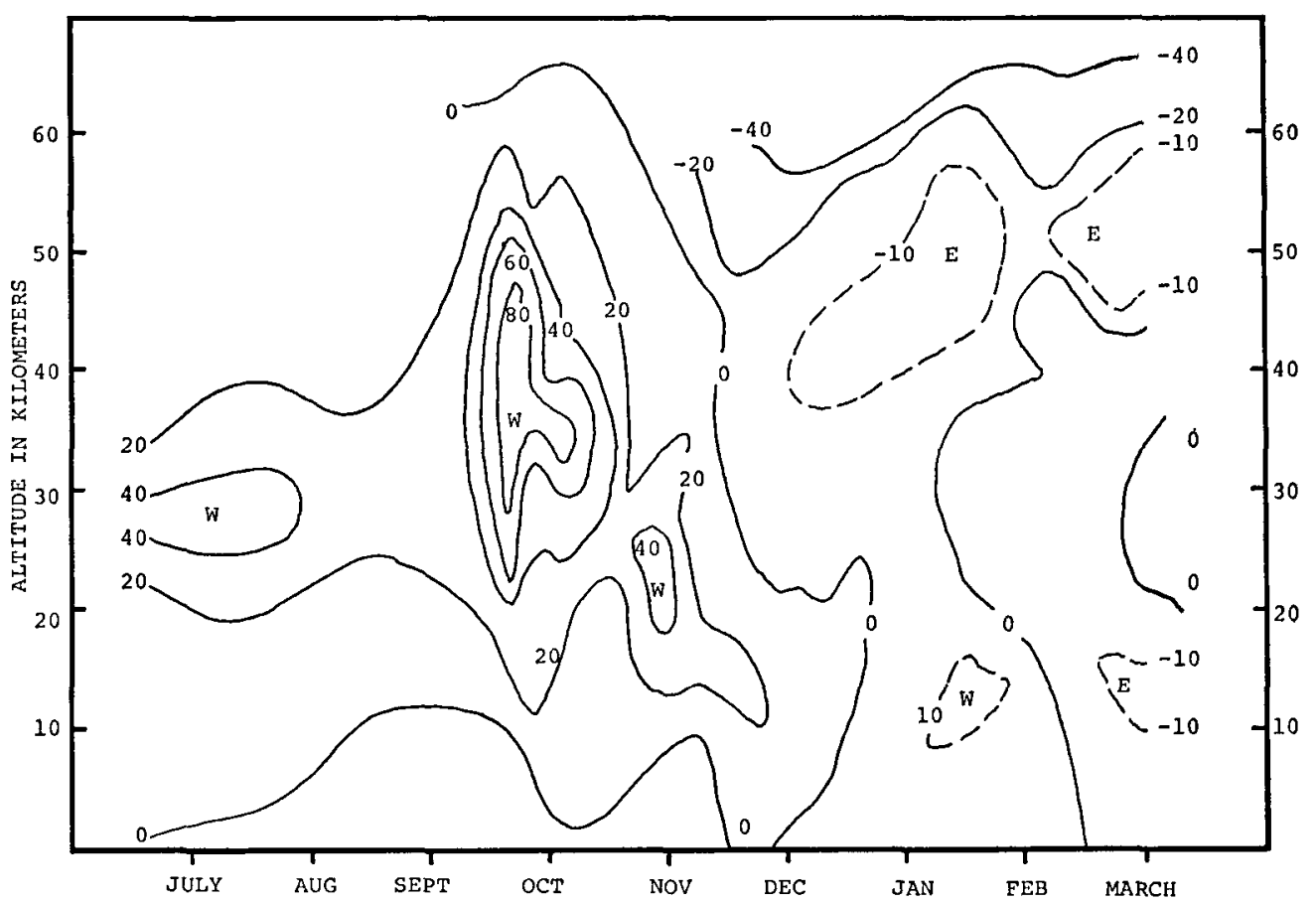

FIG. 2. Time-height cross section for McMurdo winds (July 1962-March 1963) west (+) and east (-) components in $\mathrm{m} \mathrm{sec}^{-1}$.

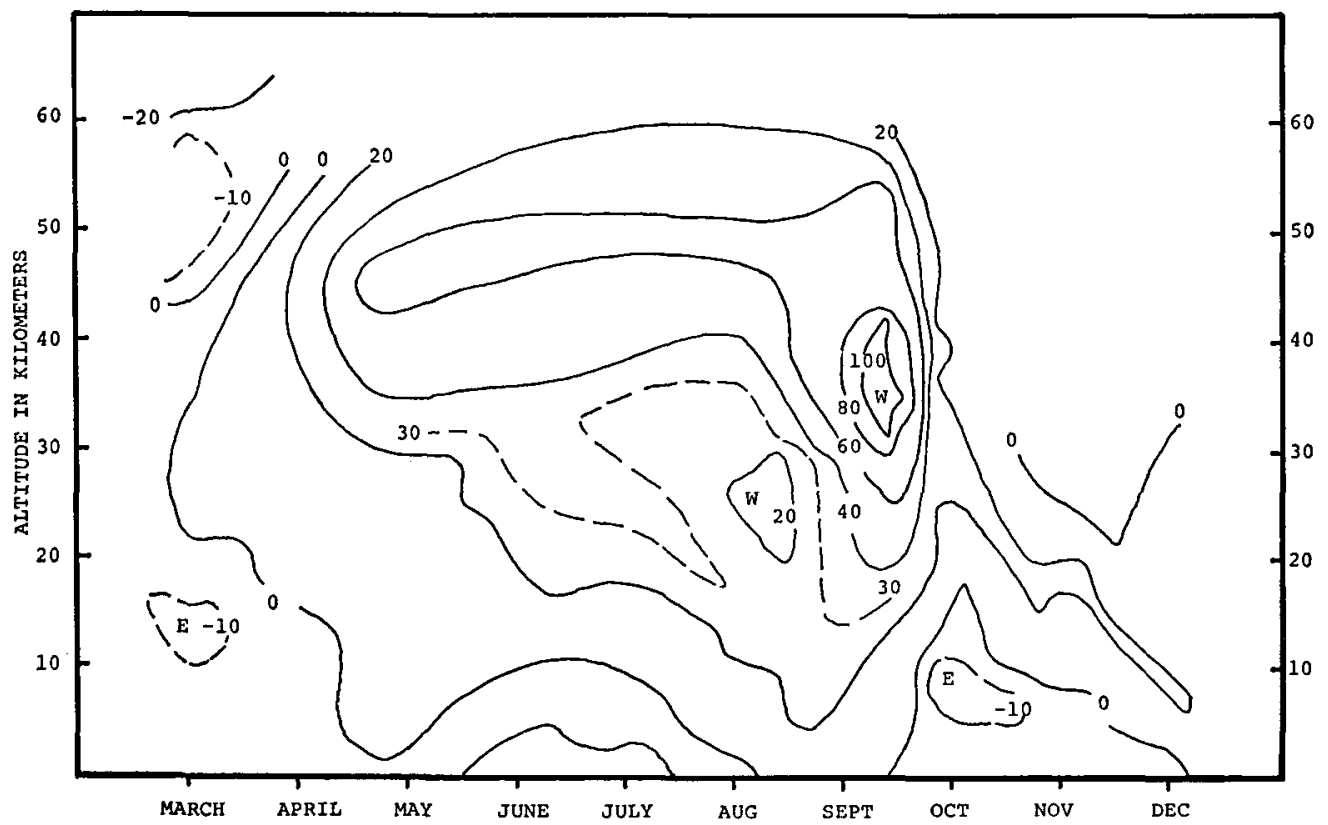

FIG. 3. Time-height cross section for McMurdo winds (March 1963-December 1963) west ( + ) and east ( - ) components in $\mathrm{m} \mathrm{sec}^{-1}$. 


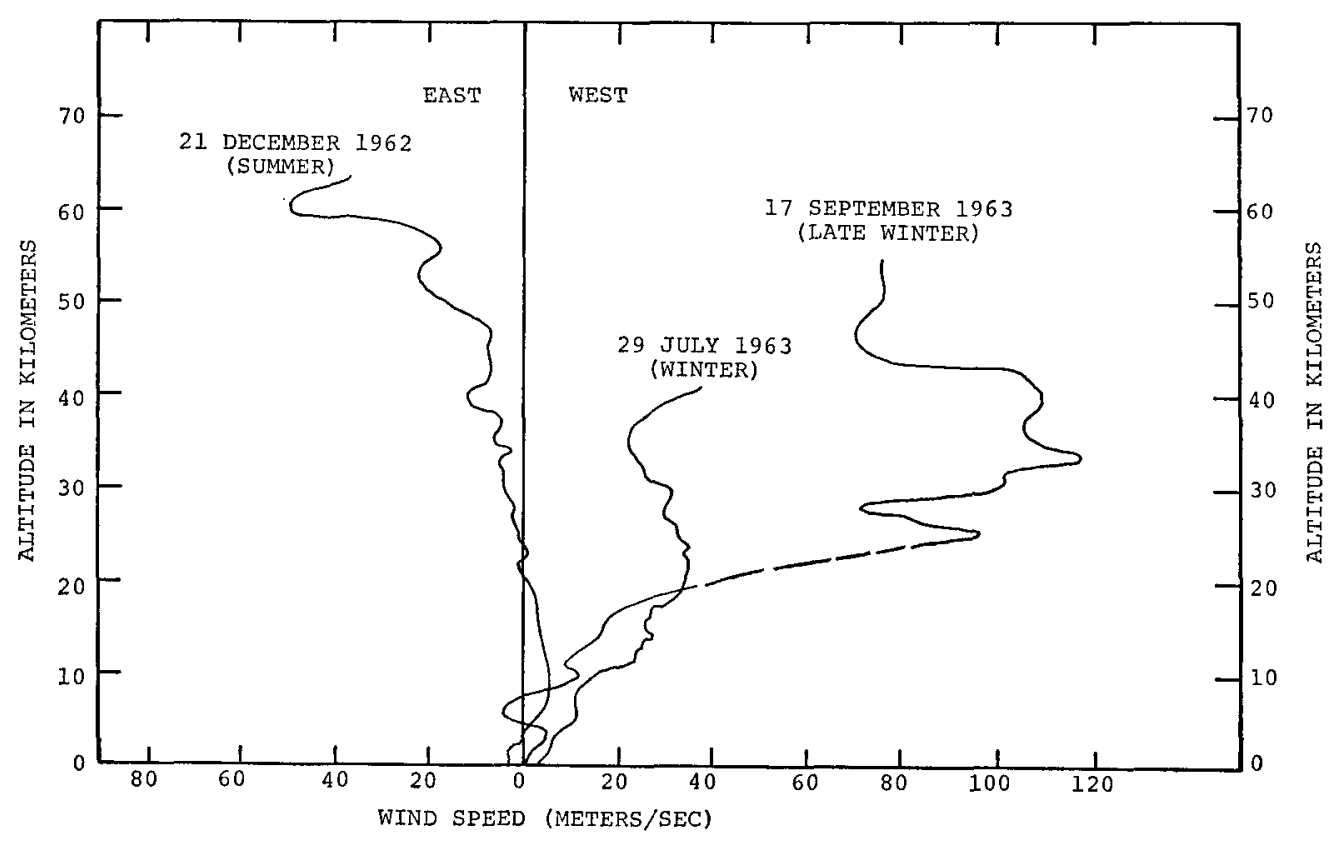

Frg. 4. Typical McMurdo zonal wind profiles for summer, winter and late winter.

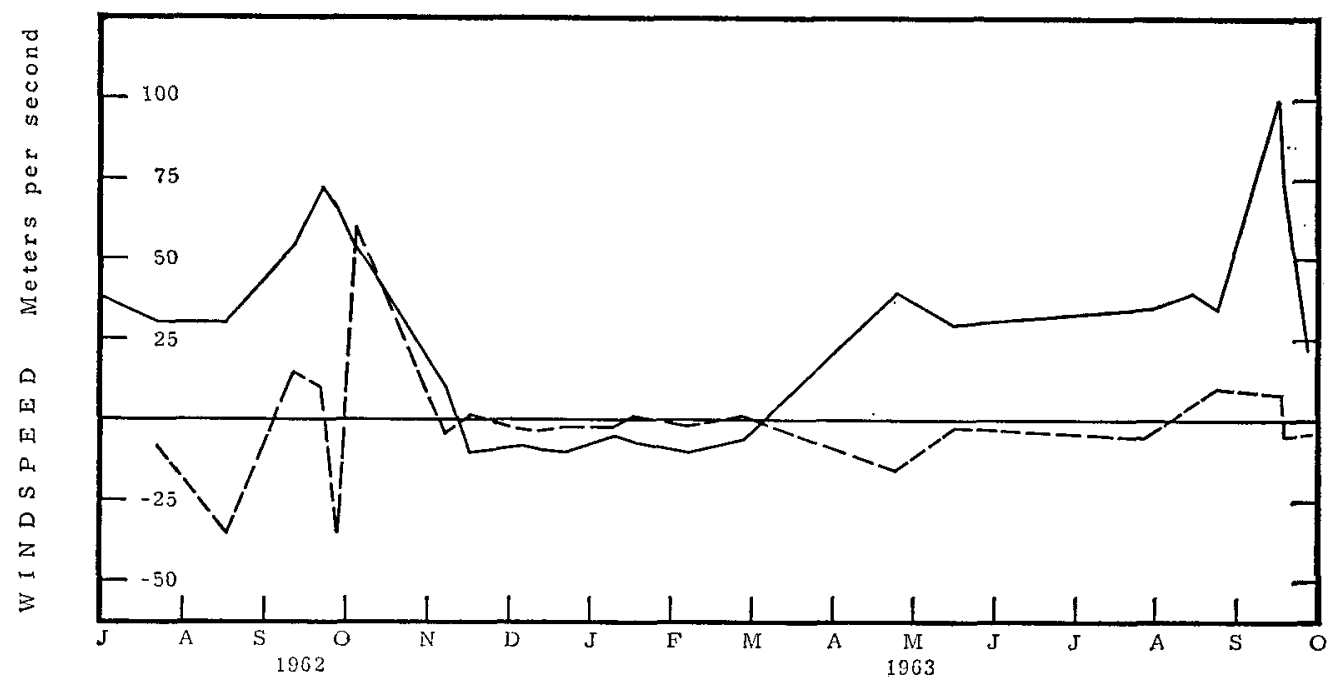

T I M E

FIG. 5. Zonal flow (solid line) obtained by averaging the individual soundings over a 10 -km layer centered at $40 \mathrm{~km}$. Meridional flow is shown by dashed line. Positive values refer to west and south components.

ized by a strong westerly jet at $35 \mathrm{~km}$ followed by the return to summer circulation. Selected soundings characteristic of the three periods are shown in Fig. 4.

The occurrence of the westerly winds in late March coincided with the departure of sunlight. The westerly winds grew in strength throughout the continuous darkness period from mid-May through mid-July. This was evident at all altitudes to $50 \mathrm{~km}$. With the return of daylight in late winter, a rapid buildup of winds with maximum strength near $35 \mathrm{~km}$. became predominate.
Shortly before continuous daylight began again, the westerly jet disappeared and the summer circulation began. During the summer months of November, December, January, and February, light easterly winds of the order of $5-20 \mathrm{~m} \mathrm{sec}^{-1}$ appeared at all altitudes to $50 \mathrm{~km}$.

Webb (1964), in an analysis of MRN data, devised a technique for showing the seasonal reversal of winds at various times throughout the year. Using the mean flow over a $10-\mathrm{km}$ layer centered at $50 \mathrm{~km}$ as an indi- 


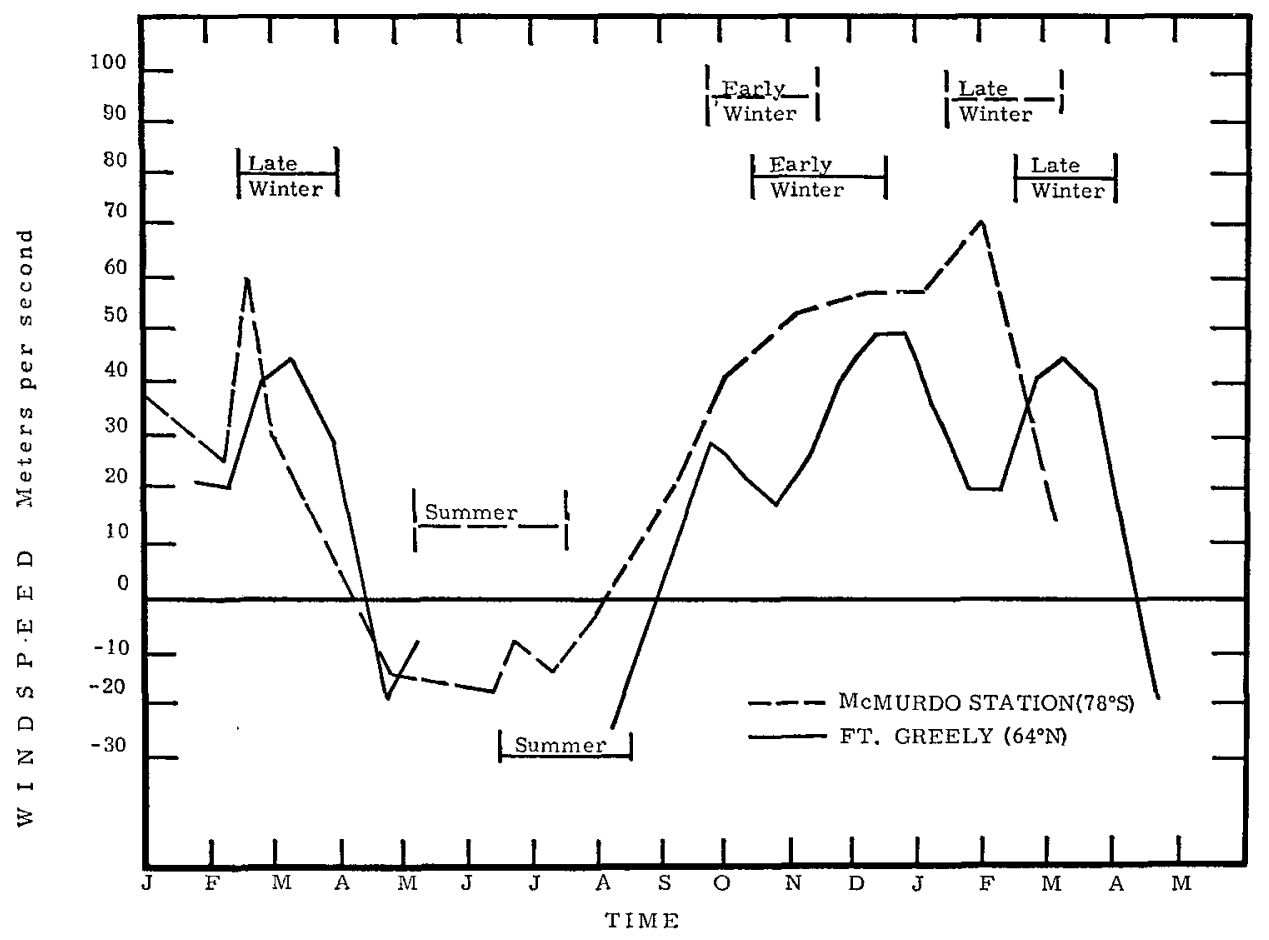

Fug. 6. Comparison of zonal flow based on Arctic and Antarctic data.

cator of the circulation, the reversals which occur from summer to winter and winter to summer are clearly demonstrated. Using the same technique at $40 \mathrm{~km}$, the shifts from winter to summer and summer to winter are shown in Fig. 5. The shift from winter to summer was a rapid and dramatic change, occurring entirely within the month of October. The summer to winter shift was slow, gradual, and unspectacular.

The meridional flow is also plotted in Fig. 5. A situation similar to the rapid shift from north to south accompanying the large temperature change between 27 September and 3 October of 1962 was not detected in 1963. While this change in meridional flow was no doubt closely linked with the sudden or "explosive" warming phenomenon, indications from radiosonde data were that a similar shift in meridional flow occurred during the third week in October of 1963, unfortunately after all available rocket vehicles had been expended.

Comparison of Arctic and Antarctic data can be performed by shifting the McMurdo data so that the equinoxes will coincide, winter data from Ft. Greely (64N) are plotted with McMurdo data in Fig. 6. This is again the mean zonal flow at $50 \mathrm{~km}$. Summer easterly circulation at the two stations seems to coincide, but the Southern Hemisphere data indicates an early shift from the winter regime. The summer season at McMurdo is shorter, possibly due to the shorter daylight period at the higher latitude. Winter westerlies begin sooner at greater velocities than were measured at Ft. Greely.
Southern Hemisphere data indicate a continued buildup throughout the winter season; Arctic data show maximum westerly strength in early winter, decreasing until early spring when the reversal occurs.

\section{Seasonal temperature structure}

The time-height cross section of temperatures is shown in Figs. 7 and 8. During the two winter seasons observed, minimum temperatures were recorded near $20 \mathrm{~km}$. Temperatures decreased steadily after the disappearance of the sun and at $20 \mathrm{~km}$ the decrease measured about $0.3 \mathrm{C}$ per day. The minimum temperature was recorded at $-86 \mathrm{C}$ at $20 \mathrm{~km}$. This temperature persisted throughout July and August to mid-September. Near the end of September, the temperature rises rapidly at about $1.4 \mathrm{C}$ per day at $20 \mathrm{~km}$, to stabilize at $-40 \mathrm{C}$ during the summer season.

Rotolante (1964) surmised that the disturbance detected at $45 \mathrm{~km}$ on 27 September 1962 propagated downward, accounting for the rapid rise in temperature which was experienced on 3 October 1962. A similar disturbance was not detected with rocketsonde observations during 1963. Indications from radiosonde data were that the sudden warming occurred in 1963 during the third week in October.

Hanson (1960) detailed the stratospheric warming which occurred in October of 1958 at the South Pole; he pointed out that similar warmings were observed at all Antarctic stations within 24 hours. He also indicates 


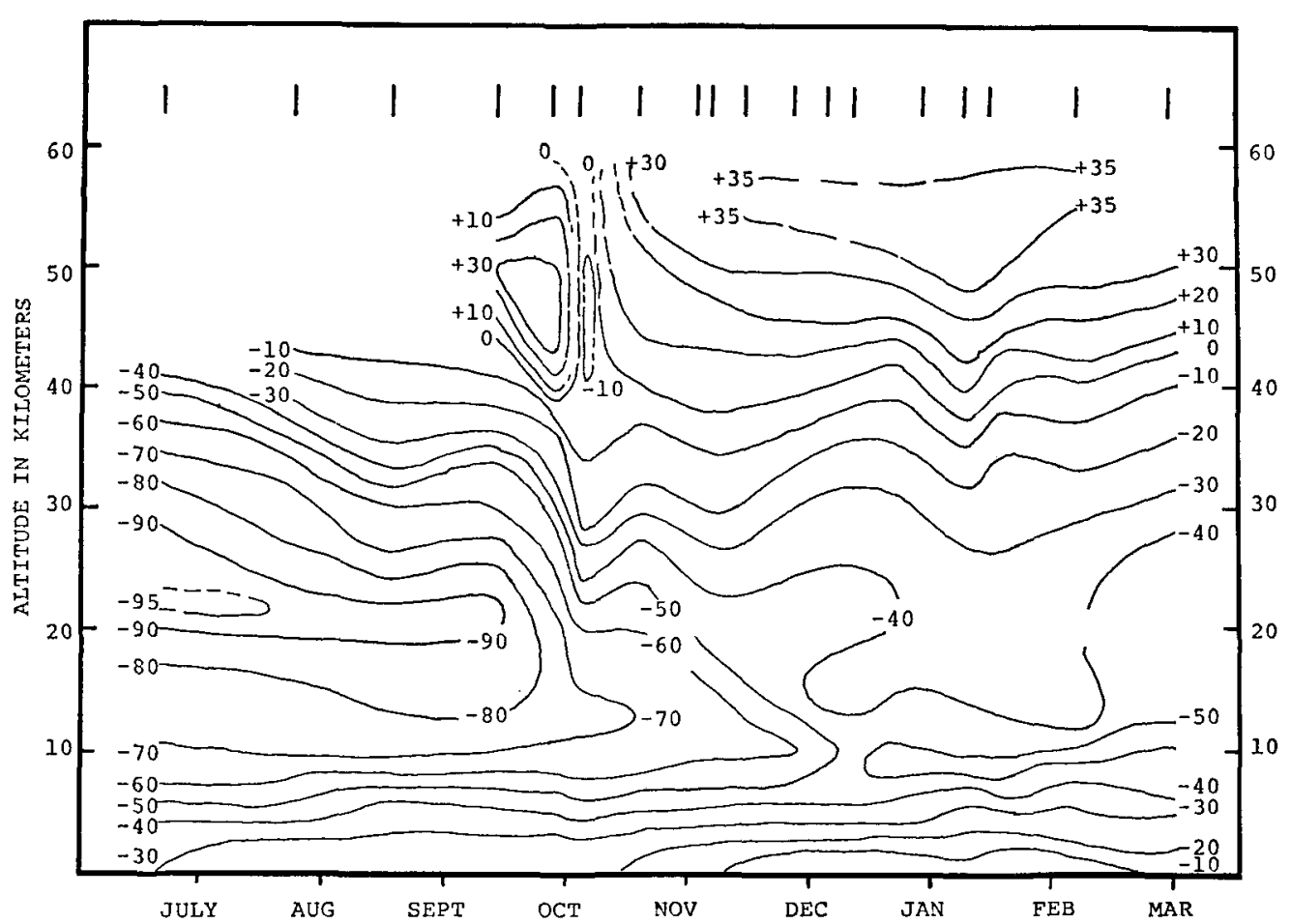

FIG. 7. Time-height cross section for McMurdo temperatures (July 1962-March 1963) in deg C.

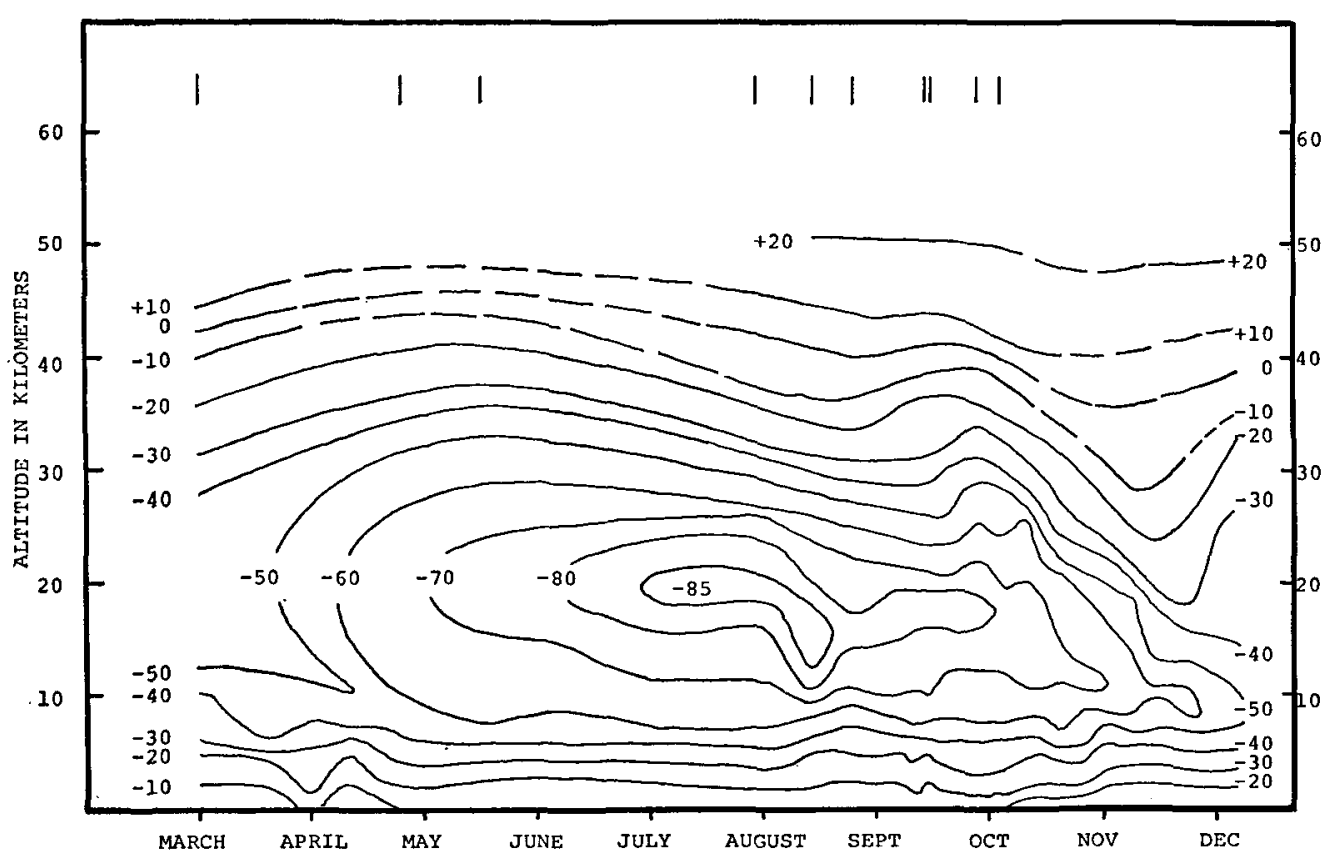

FIG. 8. Time-height cross section for McMurdo temperatures (March 1963-December 1963) in deg C. 
that the warming occurred in October of 1957, giving rise to the concentrated effort made at the South Pole stations to obtain high altitude data in 1958. It would appear on the basis of limited observations that the major disturbance of the year occurs sometime during the first three weeks in October. With this in mind, future operations in the Antarctic should include an increased effort during this period.

The outstanding feature of summer temperatures is the $15-\mathrm{km}$ layer of relatively steady $-40 \mathrm{C}$ that is centered at $20 \mathrm{~km}$. Winds during this period are easterly, calm, and steady, indicating the circulation under continuous daylight conditions.

The temperature range at $20 \mathrm{~km}$ is the most extreme for all altitudes through which temperatures were measured. Table 2 summarizes the temperature range exhibited at various altitudes. The scarcity of data at the $50-\mathrm{km}$ level makes an estimate of the temperature range difficult. An approximate estimate based on the time-height temperature profile would be from $+30 \mathrm{C}$ to $+10 \mathrm{C}$, uncorrected for thermistor error at that altitude. Wagner (1961) has outlined a series of corrections based on the fall rate of the sensor for altitudes above $40 \mathrm{~km}$.

Comparison with Ft. Greely temperatures is diffcult, since for some months rocketsonde observations were not made. Summer observations were not made at Ft. Greely during June, July, August, September, and October of 1963.

Winter data from Ft. Greely indicate that the Northern Hemisphere temperatures are 15-20 degrees warmer than corresponding temperatures in the Southern Hemisphere, a situation which had been evident from research (Palmer, 1959) previous to the rocket observations.

\section{Summary}

From the initial sampling of the Antarctic upper stratosphere it appears that the most interesting and active period in south polar regions is the SeptemberOctober early spring period. This period is marked by the winter-summer reversal of winds, immediately preceded by the strong zonal jet at $35 \mathrm{~km}$. The sudden or "explosive" warming occurs during this period, and this event appears to propagate downward from an initial disturbance above $50 \mathrm{~km}$. High altitude radiosondes are capable of detecting this disturbance, and all Antarctic stations notice the abrupt change in temperature within 48 hours of each other.

The warming and the appearance of the circumpolar jet stream at $35 \mathrm{~km}$ must be closely connected to the increase in available heat brought about by the return of sunlight in the August-September period. A better understanding of the mechanisms involved could be obtained from a detailed study of the meridional flow regime. A network of stations some 10 degrees apart
TABLE 2. Summary of temperature ranges at various altitudes.

\begin{tabular}{|c|c|}
\hline Altitude & Temperature range \\
\hline $10 \mathrm{~km}$ & $\begin{array}{l}-74 \mathrm{C} \text { in early September to }-50 \mathrm{C} \text { January thru } \\
\text { April }\end{array}$ \\
\hline $20 \mathrm{~km}$ & $\begin{array}{l}-90 \mathrm{C} \text { during July, August and early September to } \\
-38 \mathrm{C} \text { during January and February }\end{array}$ \\
\hline $30 \mathrm{~km}$ & $\begin{array}{l}-58 \mathrm{C} \text { during May, June and July to }-25 \mathrm{C} \text { during } \\
\text { October, November and December }\end{array}$ \\
\hline $40 \mathrm{~km}$ & $\begin{array}{l}\text {-20C during April, May, June to +04C October, } \\
\text { November, December, January }\end{array}$ \\
\hline
\end{tabular}

along approximately the same meridian would probably be sufficient for this purpose.

The semi-controlled conditions existing in the Antarctic, the variation of sunlight and available radiant energy, make it the ideal place to study basic atmospheric processes in the stratosphere. Future studies are of course absolutely necessary in this region.

Acknowledgments. The author is greatly indebted to Mr. Willis Webb for his suggestions and helpful criticisms. Mr. Ralph Rotolante and Miss Alice Marie Parra were most helpful in preparation of the graphs and in critical reading.

\section{REFERENCES}

Hanson, K. J., 1960: A case study of the explosive stratospheric warming over the Antartic, October 1958. Antarctic Meteorology, New York, Pergamon Press, 128-137.

Kellogg, W. W., and G. Schilling, 1950: Survey of data and theroretical analysis of the upper atmosphere. U. S. Weather Bureau, Washington, D. C., Contract cwb-7904.

Miers, B. T., and N. J. Beyers, 1963: Rocketsonde wind and temperature measurements between 30 and 70 kilometers for selected stations. Paper presented at the AIAA-AMS Meeting on Meteorological Support for Aerospace Testing Operation, July 10-12, 1963, Ft. Collins, Colo.

Murgatroyd, R. J., 1957: Winds and temperatures between 20 and $100 \mathrm{~km}-\mathrm{a}$ review. Quart. J. R. Meteor. Soc., 83, $417-458$.

Palmer, C. E., 1959: The stratospheric polar vortex in winter. J. Geophys. Res., 64, 749-764.

Rotolante, R. A., 1963: Establishment of rocket tracking facilities, McMurdo Station, Antarctica. Schellenger Research Laboratories, Texas Western College, El Paso, Texas, Antarctic Report NSF-1.

,- 1964 : Meteorological rocket data profile of the stratosphere, McMurdo, Antarctica. Schellenger Research Laboratories, Texas Western College, El Paso, Texas, Antarctic Report NSF-2.

Teweles, S., and F. B. Finger, 1958: An abrupt change in stratospheric circulation beginning in mid-January 1958. Mon. Wea. Rev., 86, 23-28.

Wagner, N. K., 1961: Theoretical time constant and radiation error of a rocketsonde thermistor. J. Meleor., 18, 606-614.

Webb, W. L., 1964: The dynamic stratosphere. Astronautics and Aeronautics, (March) 62-68.

Wexler, H., and J. J. Rubin, 1961: Antarctic Meteorology, Science in Antarctica, Part II. National Academy of SciencesNational Research Council Publication 878, 6-24. 